\title{
Evaluation of Nutrient Management in Coconut Based Cropping System for Thanjavur Delta Region
}

\author{
A. Selva Rani $^{1}$, A. Karthikeyan ${ }^{1}$ and H. P. Maheswarappa ${ }^{2 *}$ \\ ${ }^{1}$ AICRP on Palms, Coconut Research Station, Veppankulam, Thanjavur Dt. Tamil Nadu, India \\ ${ }^{2}$ AICRP on Palms, ICAR - Central Plantation Crops Research Institute, Kasaragod - 671 124, \\ Kerala, India
}

*Corresponding author

\begin{tabular}{|l|}
\hline Key w o r d s \\
Coconut, Organic, \\
Inorganic, \\
$\begin{array}{l}\text { Intercrop, Cocoa, } \\
\text { pepper, Banana }\end{array}$ \\
\hline Article Info \\
\hline $\begin{array}{l}\text { Accepted: } \\
15 \text { November } 2019 \\
\text { Available Online: } \\
10 \text { December } 2019\end{array}$ \\
\hline
\end{tabular}

\section{A B S T R A C T}

\section{Introduction}

Organic manures are important in sustaining soil fertility and productivity especially with a perennial crop like coconut (Cocos nucifera
L). Application of organic manure viz., vermicopost, vermiwash, biofertilizer, composted coir pith and in situ green manuring enormously improved the growth and yield in coconut. Organic manuring is 
seldom practiced in coconut cultivation. Maintenance of soil organic matter is very essential for the successful growth and yield of crops. Coconut is predominantly grown in sandy soils which often lack adequate quantity of organic matter. In tropical soils the organic matter content has to be enhanced regularly in view of the rapid oxidation and exhaustion. It has been observed that most coconut growing soils are deficient in one or more nutrients. Indian soils are usually very poor in organic matter and nitrogen (Sumathykuttyamma, 1977). The improvement in yield is likely to be due to the addition of nitrogen through the green manure crop and improvement of organic matter in the soil. It is recorded that the application of organic matter like coconut pith, forest leaves and cattle manure had considerably improved the growth and flowering in coconut (Anon, 1980). Thomas and Shantaram (1984) observed beneficial effects of in situ incorporation of green manure in coconut and stressed the importance of green manuring in improving the activity of soil microflora and suppression of soil-borne plant pathogens which might be beneficial for increased coconut production. In most coconut growing areas, the interspaces between the palms are cultivated with flower crop, cocoa, pepper and banana. This paper describes studies on evaluation of nutrient management, carried out at Coconut Research Station, Veppankulam, Thanjavur District, Tamil Nadu, India.

\section{Materials and Methods}

The experiment was conducted at AICRP on Palms Centre, Coconut Research Station, Veppankulam in Tamil Nadu state for five years from 2013 to 2018 in a 45 years old coconut garden of East Coast Tall variety planted at a spacing of $7.5 \mathrm{~m} \times 7.5 \mathrm{~m}$. Average annual rainfall of $1125 \mathrm{~mm}$ distributed mainly during April and June to December. The soil of the experimental site was sandy loam, medium in available nitrogen and phosphorous and low in potassium. The coconut based cropping system comprises of Coconut $(\mathrm{ECT})+$ Black pepper (Panniyur 1) + Banana (G9) + Cocoa (F1 hybrid) in East Coast region of Tamil Nadu with four nutrient management treatments viz., $\mathrm{T}_{1}-75 \%$ of recommended NPK $+25 \%$ of $\mathrm{N}$ through organic recycling with vermicompost, $\mathrm{T}_{2}-50$ $\%$ of recommended NPK $+50 \%$ of $\mathrm{N}$ through organic recycling with vermicompost + vermiwash + biofertilizer + in situ green manuring, $\mathrm{T}_{3}-$ Fully organic $100 \%$ of $\mathrm{N}$ through organic recycling with vermicompost + vermiwash + biofertilizer + in situ green manuring + green leaf manuring (Glyricidia leaves) + composted coir pith husk incorporation (once in 3 years) and mulching with coconut leaves, $\mathrm{T}_{4}-$ Control (recommended NPK and organic manure) during 2013 - 2018. The intercropping system with coconut was compared with the sole crop of coconut. The experiment was nonreplicated. The observation on the nut yield of coconut and intercrops yield were recorded. The coconut crop (nut) equivalent yield (CEY) of intercrops was computed based on the selling price of cocoa, pepper, banana and coconut. The economics of the cropping system was worked out based the market price of inputs and produce prevailed during respective years. The data on yield and returns of five years was averaged to get the data of mean yield and returns.

\section{Results and Discussion}

\section{Growth and yield of coconut}

Coconut is highly exhaustive palm and it is difficult to meet the demand of plant through fertilizers alone. Hence, to reduce the cost on inorganic fertilizers and to sustain yields, available organic resources from coconut, component crops, vermicompost and biofertilizers are recommended. Use of these 
organics in combination with appropriate ratio of fertilizers is beneficial in increasing the crop yield and maintaining soil health.

The mean data of five years from 2013 to 2018 showed that the nut yield of coconut was found to be considerably influenced by inorganic and organic levels of nutrient management (Table 1).

Nutrient management at 50 per cent inorganic fertilizer with 50 per cent organic nutrient management recorded higher nut yield of 118 numbers palm $^{-1}$ year $^{-1}$ as compared to mono cropping of coconut with recommended dose of inorganic fertilizer application (103 nuts $^{-1}$ palm $^{-1}$ year $^{-1}$ ) during the period of $2013-18$. Among the different treatments, $50 \%$ of recommended NPK $+50 \%$ of organic recycling with vermicompost + vermiwash + biofertilizer + in situ green manuring performed well as compare to others. The application of organic manure has numerous advantages, such as, improving soil physical property parameters, i.e., water holding capacity, water movement, infiltration rate, bulk density, porosity, tilth, aeration, soil structure, aggregate stability, etc. (Saha et al., 2010). The positive effects of organic waste on coconut growing soils were reported in several studies (Odlare et al., 2007; Jedidi et al., 2004).

\section{Yield of coconut and component crops}

Nut yield, cocoa dry bean yield, fruit yield of banana and dried black pepper yield of coconut based cropping system was found to be considerably influenced by inorganic and organic levels of nutrient management (Table 2).

Treatment $\mathrm{T}_{2}$ - nutrient management at 50 per cent inorganic fertilizer with 50 per cent organic nutrient management recorded higher nut yield of coconut $\left(20,650\right.$ nuts. ha ${ }^{-1}$ year $\left.^{-1}\right)$, dry bean yield of cocoa $\left(230.20 \mathrm{~kg}\right.$. ha $\left.{ }^{-1}\right)$, fruit yield of banana $\left(23,345 \mathrm{~kg}\right.$. ha $\left.{ }^{-1}\right)$ and dried black pepper $\left(39.80 \mathrm{~kg}\right.$. ha ${ }^{-1}$ ) followed by 100 per cent of organic nutrient management viz., organic recycling with vermicompost + vermiwash + biofertilizer + in situ green manuring + green leaf manuring (Glyricidia leaves) + composted coir pith husk incorporation (once in 3 years) and mulching with coconut leaves.

Excessive fertilizer applications are also contaminating surface and underground water bodies especially by nitrate leaching (Pimentel, 1996) and causing detrimental effects on environment, which in turn is causing serious hazards to human and animal health. Vermicompost organic manure in crop production is a better alternative for improving soil health, crop productivity and quality as it exert a significant positive influence on soil properties and microbial population. The earthworms accelerate decomposition of plant litter and organic matter and improve soil fertility by releasing mineral elements in the forms that are easily uptake by plants (Curry, 1987). Organic matter addition generating from each component crops act as barrier to loss of soil and moisture in surface runoff, facilitate nutrient addition and improve the microclimate. Also, air relative humidity will be higher and soil water availability for intercrops will be maintained at a higher level because of less evaporation from the soil and lower crop transpiration rates.

\section{Coconut (nut) equivalent yield}

The yield of component crops in terms of coconut equivalent yield (Table 3) was significantly higher with cocoa (3,933 nuts ha1 year-1), banana $(19,454$ nuts ha- 1 year-1) and pepper (1,990 nuts ha-1 year-1) followed by T3 fully organic nutrient management of cocoa (3926 nuts ha-1 year-1), banana $(18,447$ nuts ha-1 year-1) and pepper (1,840 nuts ha-1 
year-1). The productivity of the intercropping with coconut in terms of coconut crop (nut) equivalent yield was significantly higher in 50 $\%$ of recommended NPK $+50 \%$ of $\mathrm{N}$ through organic recycling with vermicompost + vermiwash + biofertilizer + in situ green manuring $\left(25,377\right.$ nuts ha ${ }^{-1}$ year $\left.^{-1}\right)$.

These experiments demonstrate the possibility of in situ cultivation of green manure crops in coconut basins and their incorporation into the soil to provide nitrogen and to enhance the organic matter status of the soil. Bio-fertilizers are low cost, effective and renewable source of plant nutrients to supplement chemical fertilizers. They are well recognized as an important component of integrated plant nutrient management for sustainable agriculture and hold a great promise to improve crop yield (Narula et al., 2005).

These are biologically active inputs and contain one or more types of beneficial microorganisms, such as, bacteria, algae or fungi (Boraste et al., 2009). These micro-organisms have the ability to fix atmospheric nitrogen either by living symbiotically with the roots of leguminous plants or non-symbiotically (free living) to transform atmospheric or nutrients from non-usable to usable form through biological processes (Amanullah et al., 2012).

Economics of nutrient management in CBCS

Treatment $\mathrm{T}_{2}$ - nutrient management at 50 per cent inorganic fertilizer with 50 per cent organic nutrient management recorded the highest net income of Rs.354244 ha $^{-1}$ year $^{-1}$ (Table 4) followed by 100 per cent of organic nutrient management viz., organic recycling with vermicompost + vermiwash + biofertilizer + in situ green manuring + green leaf manuring (Glyricidia leaves) + composted coir pith husk incorporation (once in 3 years) and mulching with coconut leaves (Rs.330819 $\mathrm{ha}^{-1}$ year $\left.^{-1}\right)$. The lowest net income of Rs.118645 ha $^{-1}$ year $^{-1}$ was registered in mono cropping of coconut with recommended dose of fertilizer application. Similar results of increased economic income in the intercropping systems of coconut with field crops (Shanthamallaiah et al., 1982; Hanumanthappa et al., 1996), vegetables (Basavaraju et al., 2008) and medicinal and aromatic plants (Maheswarappa, 1997; Basavaraju et al., 2011; Maheswarappa et al., 2013) were also reported.

Table.1 Effect of nutrient management on nut yield of coconut in coconut based cropping system

\begin{tabular}{|c|c|c|c|c|c|c|}
\hline \multirow[t]{2}{*}{ Treatments } & \multicolumn{6}{|c|}{$\begin{array}{l}\text { Mean nut yield of coconut }-2013-18 \\
\left(\text { No. of nuts }{ }^{-1} \text { palm }^{-1} \text { year }^{-1}\right)\end{array}$} \\
\hline & $2013-2014$ & 2014-2015 & $2015-2016$ & $2016-2017$ & $2017-2018$ & $\begin{array}{l}\text { Mean } \\
\text { yield }\end{array}$ \\
\hline $\begin{array}{r}T_{1}-75 \% \text { RDF } \\
+25 \% \text { Organic }\end{array}$ & 98 & 100 & 108 & 112 & 110 & 106 \\
\hline $\begin{array}{r}\mathbf{T}_{2}-\mathbf{5 0} \% \text { RDF } \\
+\mathbf{5 0} \% \text { Organic }\end{array}$ & 112 & 108 & 122 & 123 & 125 & 118 \\
\hline $\begin{array}{c}T_{3}-100 \% \\
\text { Organic }\end{array}$ & 110 & 106 & 113 & 115 & 120 & 113 \\
\hline $\begin{array}{l}\text { T4 - Control } \\
\text { (Rec. RDF with } \\
\text { organic) }\end{array}$ & 95 & 98 & 105 & 108 & 107 & 103 \\
\hline
\end{tabular}


Table.2 Effect of nutrient management on yield of coconut and component crops

\begin{tabular}{|c|c|c|c|c|}
\hline \multirow[t]{2}{*}{ Treatments } & \multicolumn{4}{|c|}{$\begin{array}{l}\text { Mean yield }\left(\mathrm{kg}^{\text {. ha }}{ }^{-1}\right) \\
(2013 \text { - 2018) }\end{array}$} \\
\hline & $\begin{array}{l}\text { Coconut } \\
\left(\text { Nuts ha }^{-1}\right)\end{array}$ & $\begin{array}{l}\text { Cocoa } \\
\left(\mathrm{kg} . \mathrm{ha}^{-1}\right)\end{array}$ & $\begin{array}{l}\text { Banana } \\
\left(\mathrm{kg} . \mathrm{ha}^{-1}\right)\end{array}$ & $\begin{array}{l}\text { Pepper } \\
\left(\text { kg. ha- }{ }^{-1}\right)\end{array}$ \\
\hline $\begin{array}{c}\mathrm{T}_{1}-75 \% \mathrm{RDF}+25 \% \\
\text { Organic }\end{array}$ & 18550 & 210.00 & 21620 & 37.20 \\
\hline $\begin{array}{c}\mathrm{T}_{2}-\mathbf{5 0} \% \mathrm{RDF}+\mathbf{5 0} \% \\
\text { Organic }\end{array}$ & 20650 & 230.20 & 23345 & 39.80 \\
\hline$T_{3}-100 \%$ Organic & 19775 & 229.80 & 22136 & 36.80 \\
\hline $\begin{array}{c}\text { T4 - Control } \\
\text { (Rec. RDF with organic ) }\end{array}$ & 18025 & - & - & - \\
\hline
\end{tabular}

Table.3 Effect of nutrient management on Coconut (nut) equivalent yield $\mathrm{kg} \mathrm{ha}^{-1}$ of CBCS

\begin{tabular}{|c|c|c|c|c|}
\hline \multirow[t]{2}{*}{ Treatment } & \multicolumn{3}{|c|}{ Mean Coconut (nut) equivalent yield $\mathrm{kg} \mathrm{ha}^{-}$} & \multirow[t]{2}{*}{$\begin{array}{c}\text { Total } \\
\left(\text { nuts ha }^{-1} \text { year }^{-1}\right)\end{array}$} \\
\hline & Cocoa & Banana & Pepper & \\
\hline $\begin{array}{c}\mathrm{T}_{1}-75 \% \text { RDF }+25 \\
\% \text { Organic }\end{array}$ & 3588 & 18017 & 1860 & 23464 \\
\hline $\begin{array}{c}\mathrm{T}_{2}-\mathbf{5 0} \% \mathrm{RDF}+\mathbf{5 0} \% \\
\text { Organic }\end{array}$ & 3933 & 19454 & 1990 & 25377 \\
\hline$T_{3}-100 \%$ Organic & 3926 & 18447 & 1840 & 24212 \\
\hline
\end{tabular}

Table.4 Economics of intercrops in coconut based cropping system (Rs.ha $\left.{ }^{-1}\right)$

\begin{tabular}{|c|c|c|c|c|}
\hline \multirow[t]{2}{*}{ Treatment } & \multicolumn{4}{|c|}{ Mean value of economics $\left(\right.$ Rs.ha $\left.^{-1}\right)$} \\
\hline & Gross return & $\begin{array}{l}\text { Cost of } \\
\text { cultivation }\end{array}$ & Net return & $\mathrm{B}: \mathrm{C}$ \\
\hline $\begin{array}{c}\mathrm{T}_{1}-75 \% \text { RDF }+25 \% \\
\text { Organic }\end{array}$ & 507993 & 224589 & 283409 & 2.26 \\
\hline $\begin{array}{c}\mathrm{T}_{2}-\mathbf{5 0} \% \text { RDF }+\mathbf{5 0} \% \\
\text { Organic }\end{array}$ & 551277 & 197033 & 354244 & 2.80 \\
\hline $\mathrm{T}_{3}-100 \%$ Organic & 527236 & 197568 & 330819 & 2.67 \\
\hline $\begin{array}{c}\text { T4 - Control } \\
\text { (Rec. RDF with organic ) }\end{array}$ & 248270 & 129625 & 118645 & 1.92 \\
\hline
\end{tabular}


The use of inorganic and organic fertilizers in the form of integrated nutrition management in coconut fields, it can be concluded that it has proved to become an important combination for sustainable agriculture. The addition of organic materials results in an increase of organic matter content of the soil which ultimately adds soil macro and micronutrients besides improving soil physical and chemical properties. It stimulates soil biological activities which is necessary for soil health and fertility. It concluded that may be the use of organic manures, such as vermicompost, green manure, and biofertilizers along with chemical fertilizers, is essential to suppress any possible negative impact of fertilizers on the soil and to sustain soil productivity.

\section{Acknowledgements}

The financial assistance and facilities provided by AICRP on Palms to take up this study is gratefully acknowledged. The author is thankful to the Project Co-ordinator (AICRP (P)) and The Professor and Head, Coconut Research Station, Veppankulam, for their help and encouragement during the course of investigation.

\section{References}

Amanullah, A., A. Kurd, S. Khan, M. Ahmed and J. Khan. 2012. Biofertilizer-A possible substitute of fertilizers in production of wheat variety Zardana in Balochistan. Pak. J. Agric. Res. 25(1): 44-49.

Anonymous. 1980 Annual Report for 1979. Central Plantations Crops Research Institute, Kasaragod, Kerala, India, p. 48

Basavaraju, T.B., Hanumanthappa, M., Nagaraja, K. and Boraiah, B. 2008. Coconut based cropping systems for maidan tract of Karnataka. Journal of Plantation Crops 36(3): 290-295.

Basavaraju, T.B., Nanjappa, H.V., Umesha, K., Vasundhara, M. and Arulraj, S. 2011. Intercropping of medicinal and aromatic plants in coconut gardens. Journal of Plantation Crops 39(2): 299304.

Curry, J.P. 1987. The invertebrate fauna of grassland and its influence on productivity. The composition of the fauna. Grass For. Sci., 42: 103-120.

Hanumanthappa, M., Indiresh, K.M., Shankar, S. and Palanimuthu, V. 1996. Intercropping studies in coconut plantation with different field crops under rainfed conditions of Karnataka. In Developments in Plantation Crops Research, Proceedings of the PLACROSYM-XII, Kottayam, India, pp. 203-205.

Jedidi, N., A. Hassen, O.V. Cleemput and A.M. Hiri. 2004. Microbial biomass in a soil amended with different types of organic wastes. Waste Manag. Res., 22: 93-99

Maheswarappa, H.P. 1997. Agronomic investigations on kacholam (Kaempferia galanga L.) and arrow root (Maranta arundinacea L.) grown as intercrops in coconut garden. Ph.D thesis, University of Agricultural Sciences, Bangalore, India.

Maheswarappa, H.P., Dhanapal, R., Subramanian, P. and Palaniswami, C. 2013. Evaluation of coconut based high density multi-species cropping system under organic and integrated nutrient management. Journal of Plantation Crops, 41(2): 130-135.

Narula, N. V. Kumar, B. Singh, R. Bhatia and K. Lakshminarayana. 2005. Impact of biofertilizer on grain yield in spring wheat under varying fertility condition and wheat cotton rotation. Archiv. Agro. Soil Sci. 51:79-89. 
Odlare, M., M. Pell and K. Svensson. 2007. Changes in soil chemical and microbiological properties during 4 years of application of various organic residues. Waste Manag., doi:10.1016/j.wasman.2007.06.005

Pimentel, D. 1996. Green Revolution and chemical hazards. Sci Total Environ, 188: 86-98

Saha, R., V.K. Mishra, B. Majumdar, K. Laxminarayana and P.K. Ghosh. 2010. Effect of integrated nutrient management on soil physical properties and crop productivity under a maize (Zea mays L.) - mustard (Brassica campestris L.) cropping sequence in acidic soils of northeast
India. Commun. Soil Sci. Plant Analy., 41(18): 2187-2200.

Shanthamallaiah, N.R., Venkatesha Gowda, T.N., Krishnamanohar, R. and Shivayogishwara, $\quad$ B. 1982. Proceedings of Plantation Crops Symposium-V (PLACROSYM- V), CPCRI, Kasaragod, 15-19 December, 1982, pp. 402-404.

Sumathykuttyamma, B. 1977. Soil organic matter - the need for its enrichment. Indian Coconut Journal 8: 1-2.

Thomas, G. V. and M. V. Shantaram. 1984. In situ cultivation and incorporation of green manure legumes in coconut basins. Plant and Soil 80: 373-380.

\section{How to cite this article:}

Selva Rani, A., A. Karthikeyan and Maheswarappa, H. P. 2019. Evaluation of Nutrient Management in Coconut Based Cropping System for Thanjavur Delta Region. Int.J.Curr.Microbiol.App.Sci. 8(12): 1972-1978. doi: https://doi.org/10.20546/ijcmas.2019.812.235 